\title{
Ultrastructure characters and partial mtDNA-COI haplotypes of Asian corn borer, Ostrinia furnacalis (Guenée) (Lepidoptera: Crambidae) from Indonesia
}

\author{
AHMAD TAUFIQ ARMINUDIN ${ }^{1,2, \vartheta}$, SUPUTA $^{2, v \vartheta}$, ARMAN WIJONARKO $^{2}$, Y. ANDI TRISYONO ${ }^{2}$ \\ ${ }^{1}$ Department of Agrotechnology, Faculty of Agriculture and Animal Science, Universitas Islam Negeri Sultan Syarif Kasim Riau. Jl. H.R. Subrantas Km \\ 15 No. 155, Pekanbaru 28293, Riau, Indonesia. Tel.: +62-761-562051; Fax.: +62-761-562051, `email: ataufiq@uin-suska.ac.id \\ ${ }^{2}$ Departement of Crop Protection, Faculty of Agriculture, Universitas Gadjah Mada. Jl. Flora No. 1, Bulaksumur, Sleman 55281, Yogyakarta, Indonesia. \\ Tel.: +62-274-523926, Fax.: +62-274-523926, "^email: puta@ugm.ac.id
}

Manuscript received: 20 December 2019. Revision accepted: 7 June 2020

\begin{abstract}
Arminudin AT, Suputa, Wijonarko A, Trisyono YA. 2020. Ultrastructure characters and partial mtDNA-COI haplotypes of Asian corn borer, Ostrinia furnacalis (Guenée) (Lepidoptera: Crambidae) from Indonesia. Biodiversitas 21: 2914-2922. In addition to the confirmation of the species of corn borer, we analyzed the relationship of Ostrinia furnacalis in Indonesia with that in other countries. Moths of $O$. furnacalis were collected from several areas in Java and Sumatra islands of Indonesia. Forewing and labial palpi scales were investigated under Scanning Electron Microscopy observation. A $658 \mathrm{bp}$ of $O$. furnacalis partial COI gene sequences of 1480-2138 nucleotides were downloaded from GenBank and BOLD system databases. The ridge lamellae and window characters as unique ultrastructure characters of scale were further supported by the COI gene analysis. High similarity was observed between the Java and the Philippines specimens, but they were a different haplotype compared with Sumatra's specimen. The results could provide the baseline data on the genetic variation of $O$. furnacalis in Indonesia.
\end{abstract}

Keywords: Asian corn borer, characters, COI, haplotype, moths, ultrastructure

\section{INTRODUCTION}

The Asian corn borer, Ostrinia furnacalis (Guenée, 1854) is a well-known insect pest in East Asia, Southeast Asia, and Australia (Mutuura and Munroe 1970; Frolov et al. 2007). In Indonesia, this species damages corn plantations in Sumatra, Java, Kalimantan, Sulawesi, Maluku, and Papua (Kalshoven 1981). Until now, the confirmation of $O$. furnacalis species in Indonesia was only based on the morphological characters (Mutuura and Munroe 1970; Kalshoven 1981).

It is not easy to distinguish $O$. furnacalis from $O$. nubilalis (Hübner, 1796), the European corn borer, because of similarities of their morphological characters, such as small tibiae, the wing variation, and the character of trilobed uncus of their male genitalia (Mutuura and Munroe 1970; Frolov et al. 2007). Furthermore, Yang and Zhang (2011) succeeded in revealing differences in the wing characters of both species using Scanning Electron Microscopy (SEM) by referring to the nomenclature of ultrastructural characters (Downey and Allyn 1975). This technique became a useful tool for describing unique characters of wings of Lepidoptera (Dey et al. 1998; Nakano et al. 2012; Aymone et al. 2013; Siddique et al. 2016; Ghosh and Mishra 2018).

In addition to discriminating species based on the morphological characters, polymerase chain reaction (PCR) technique provides a complementary tool based on a molecular approach. This technique is not only used to distinguish a sibling species or to ensure a species (Zhang and Hewitt 1997), but also to study phylogenetics (Sihvonen et al. 2011; Sutrisno 2015; Ashfaq et al. 2017) and genetic variation ( $\mathrm{Li}$ et al. 2014) by amplifying mitochondrial gene targets, such as sequences of cytochrome oxidase 1 (COI), cytochrome oxidase 2 (COII), and NADH dehydrogenase (ND) (Sihvonen et al. 2011; Li et al. 2014). The sequences were aligned with accession numbers available in GenBank (http://ncbi.nlm.nih.gov) using the BLAST system (Basic Local Alignment Search Tool) (Altschul et al. 1990) and DNA barcoding on BOLD systems (http://boldsystems.org) (Hebert et al. 2004; Hajibabaei et al. 2006; Hebert et al. 2013; Shashank et al. 2014) to determine the similarity.

Considering on the history of $O$. nubilalis invasion into North America (Brindley and Dicke, 1963; Mutuura and Munroe 1970), introduction of this species to Indonesia would impact on the distribution of the two local species of Ostrinia due to different reproductive abilities and invasion capabilities (Wang et al. 2017). If this happens, it would complicate the control of corn borers in Indonesia. The ability to distinguish between these two species is essential for their management. Therefore, this study aims to provide a detailed analysis of the morphological characters of $O$. furnacalis and its phylogenetics based on a partial COI gene data available in GenBank and BOLD as a complementary technique for accurate identification. 


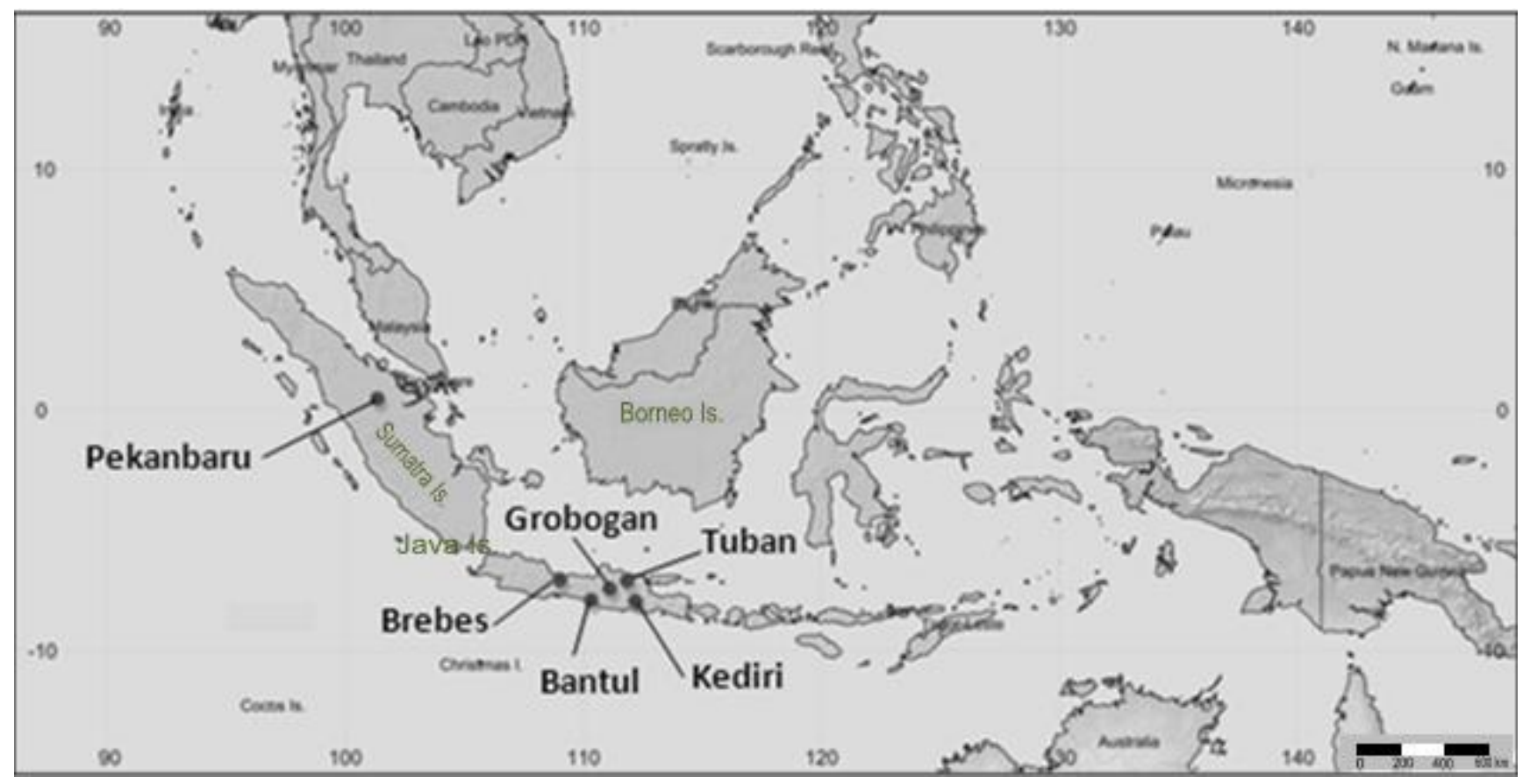

Figure 1. Samples of Ostrinia furnacalis were collected from Sumatra and Java Island of Indonesia. Created by simpleMappr, http://www.simplemappr.net

\section{MATERIALS AND METHODS}

\section{Study area}

Samples of $O$. furnacalis were collected at the larval stage from five districts in Java and one districts in Sumatra (Figure 1). In Java, samples were collected from the districts of Grobogan ( $\left.07^{\circ} 1{ }^{\prime} 29.65^{\prime \prime} \mathrm{S}, 110^{\circ} 55^{\prime} 57.59^{\prime \prime} \mathrm{E}\right)$, Brebes (07'1'47.42'S, 108 56'39.61' 'E), Tuban (07

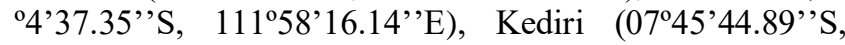
$\left.112^{\circ} 4^{\prime} 55.78^{\prime \prime} \mathrm{E}\right)$ and Bantul $\left(07^{\circ} 51^{\prime} 14,75^{\prime \prime} \mathrm{S}\right.$, $\left.110^{\circ} 15^{\prime} 12.91^{\prime \prime} \mathrm{E}\right)$. In addition, one sample was collected from the district of Pekanbaru, the Province of Riau, Sumatra $\left(0^{\circ} 24^{\prime} 48.8^{\prime}{ }^{\prime} \mathrm{N}, 101^{\circ} 24^{\prime} 38.8^{\prime \prime} \mathrm{E}\right)$.

\section{Sample collection}

In total, 182 larvae were collected and reared to reach imago stage by feeding with an artificial diet according to the formula of Y. A. Trisyono (Rahayu et al. 2018). Pupal sexing was conducted by looking at the specific character at the posterior end of the pupae (Rahayu et al. 2018). The newly emerged adults from the reared larvae and pupae, named ' $\mathrm{G} 0$ ', were fed with a $10 \%$ sugar solution until the third day, and placed in a $1.5 \mathrm{~mL}$ tube containing $95 \%$ ethanol. One or two samples from each site were used for ultrastructure and molecular analysis. All specimens have been deposited in Insect Museum, Faculty of Agriculture, Gadjah Mada University, Indonesia and GenBank (http://ncbi.nlm.nih.gov) with no. accession MK675892MK675897 for their partial COI sequences.

Ultrastructural characters of forewing and labial palpi scale

Preparation of forewing and labial palpi scales for microscopic observation and identification was performed according to Yang and Zhang (2011) with some modifications. Forewings were released from the female thorax to avoid sexual dimorphism, except one sample from Grobogan for assuring sexual dimorphism, while the labial palpi were cut carefully at the base. The M-R forewing venation area of each sample was cut to a size of ca. $1 \mathrm{~mm}^{2}$, while one part of labial palpi was also isolated intact and observed under the Leica MZ16 microscope (Leica Microsystems [Schweiz] AG, Heerbrugg, Switzerland) before SEM analysis. The samples were mounted on a metal stub using a double adhesive carbon tape, coated with platinum for approximately 15 minutes (Ghosh and Mishra 2018), and observed using JSM6510LA SEM at $15 \mathrm{kV}$.

\section{Molecular analysis}

Extraction of DNA

Genome was extracted from the thorax of six female moths from six samples using a DNA isolation GT100 mini kit (Geneaid Biotech Ltd. Taiwan). The extraction steps consisted of destruction of the sample tissue in a buffer, lysis, washing, and elution. The quality of genome was assessed by electrophoresis of each $5 \mu \mathrm{L}$ of the extracted DNA. A $1.5 \mu \mathrm{L}$ of loading dye was added, run on a $0.8 \%$ agarose gel in TBE $1 \mathrm{X}$ at $50 \mathrm{~V}$ for $50 \mathrm{~min}$, and assessed under UV light on a UV transilluminator machine. The concentration of the DNA was measured using a NanoVue Plus Spectrophotometer (GE Healthcare Life Sciences, Canada) by loading 1-2 $\mu \mathrm{L}$ of the sample into the machine.

\section{DNA amplification and sequencing}

PCR was performed using $6 \mu \mathrm{L}$ of DNA template according to the procedure of the Go taq Green (Promega- 
USA). A $12.5 \mu \mathrm{L}$ of Go taq Green and $1.5 \mu \mathrm{L}$ of each primer for COI consisting of forward (LepF 5'ATTCAACCAATCATAAAGATATTGG-3') and reverse (LepR 5'-TAAACTTCTGGATGTCCAAAAAATCA-3') primers were mixed, and then $3.5 \mu \mathrm{L}$ of nuclease-free water was added to make a volume to $25 \mu \mathrm{L}$ in a $0.2 \mathrm{~mL}$ PCR tube. Amplification of target sequence was carried out using a T100 Thermal Cycler (Bio-Rad USA) machine according to Hebert et al. (2004) and Sutrisno (2015), i.e., pre-denaturation in $95^{\circ} \mathrm{C}$ for $5 \mathrm{~min}$, followed by $35 \mathrm{x}$ cycles of $94^{\circ} \mathrm{C}$ for $1 \mathrm{~min}$, annealing $51^{\circ} \mathrm{C}$ for $1 \mathrm{~min}$, extension $72^{\circ} \mathrm{C}$ for $1 \mathrm{~min}$. The final extension was in $72^{\circ} \mathrm{C}$ for $5 \mathrm{~min}$ and cycle end in $4^{\circ} \mathrm{C}$. The PCR products were electrophoresed on a $1 \%$ agarose gel containing 1:10.000X GelRed DNA stain (Biotium-USA) and run on TBE 1X solution in an electrophoresis apparatus (Bio-Rad, USA) at $50 \mathrm{~V}$ and $400 \mathrm{~mA}$ for $50 \mathrm{~min}$ with a $1 \mathrm{~kb}$ marker. The gel was observed under a UV transilluminator and photographed using a digital camera. The successful amplicons were sent to $1^{\text {st }}$ BASE Singapore sequencing service (http://base-asia.com). The sequence products were analyzed using BioEdit ver. 7 (Hall 1999), and genetic similarity was assessed using the BLAST system in GenBank (http://ncbi.nlm.nih.gov). The phylogenetic tree was constructed through multiple alignments using CLUSTAL (Thompson et al. 1994) in MEGA 6 (Tamura et al. 2013).

\section{RESULTS AND DISCUSSION}

\section{Ultrastructure of forewing scales}

All samples of $O$. furnacalis collected from Java had more than three sharp teeth on the distal dentition of the scales, whereas the Pekanbaru sample had one tooth longer than the others (Figure 2). The ultrastructure of forewing showed large windows $(>0.5 \mu \mathrm{m})$ in almost all samples, except from the Grobogan and Kediri samples which had small windows $(<0.5 \mu \mathrm{m})$. Moreover, a trabecula existed in several windows of the Pekanbaru sample (Figure 3). Only the Grobogan sample had cross ribs (ridge lamellae) in the ultrastructure of forewing scale, ranging in number from one to three, while others only showed microribs.

\section{Ultrastructure of labial palpi scale}

Ridge lamella characteristics and windows of the ultrastructure of male and female $O$. furnacalis scales were similar, ranging from two to five, while the windows were mostly small in size $(0.1-0.2 \mu \mathrm{m})$, with some being larger $(0.3-0.4 \mu \mathrm{m})$ (Figure 4). The patterns and sizes of the windows between the ridges were unique in the Brebes sample, i.e., irregular (Figure 5).

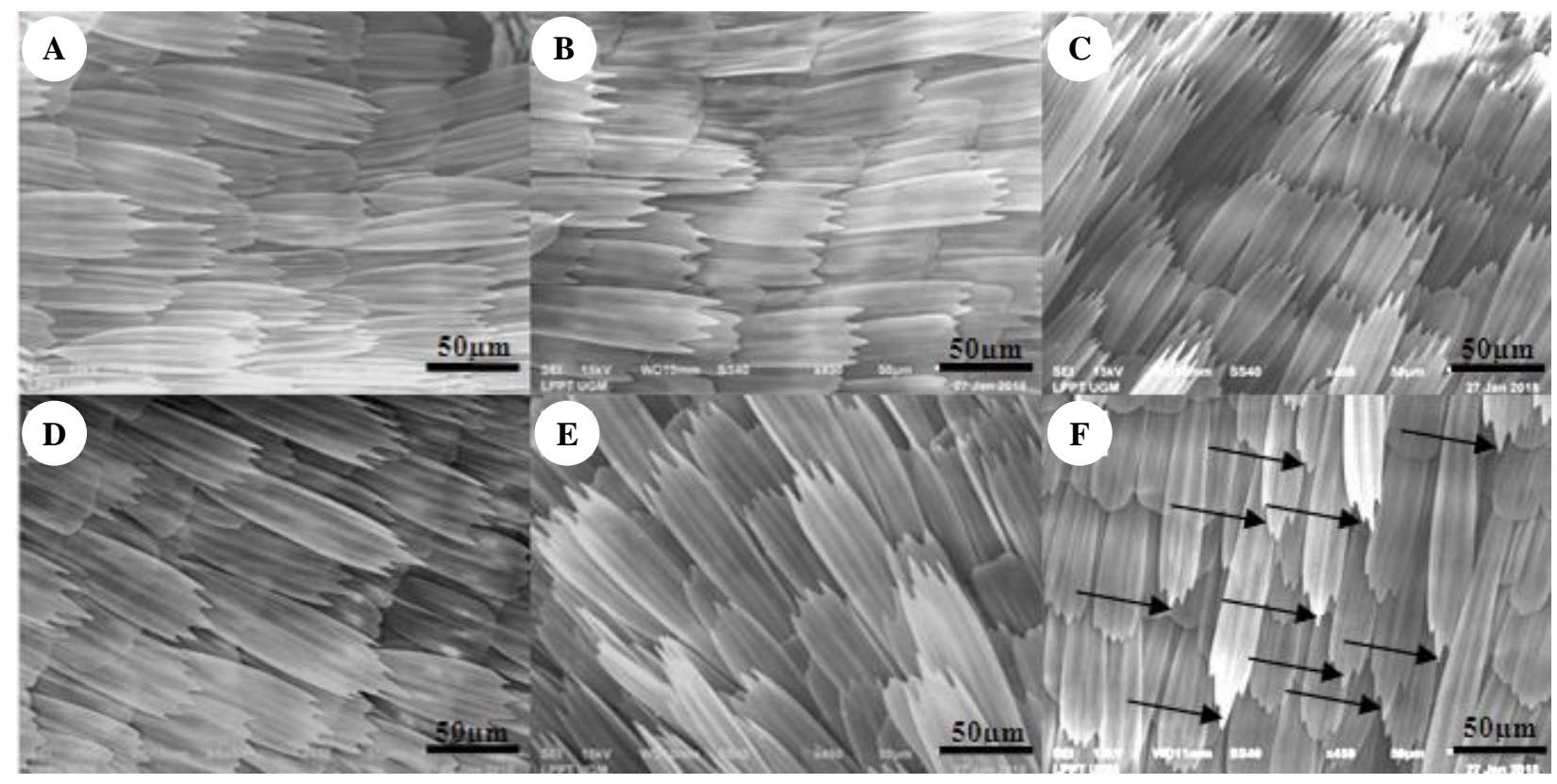

Figure 2. Distal dentition of forewing scales of the Ostrinia furnacalis from six districts in Indonesia: A. Brebes; B. Grobogan; C. Kediri; D. Tuban; E. Bantul, and F. Pekanbaru. Arrows showed longer teeth in the Pekanbaru sample compared to those from the other five samples 


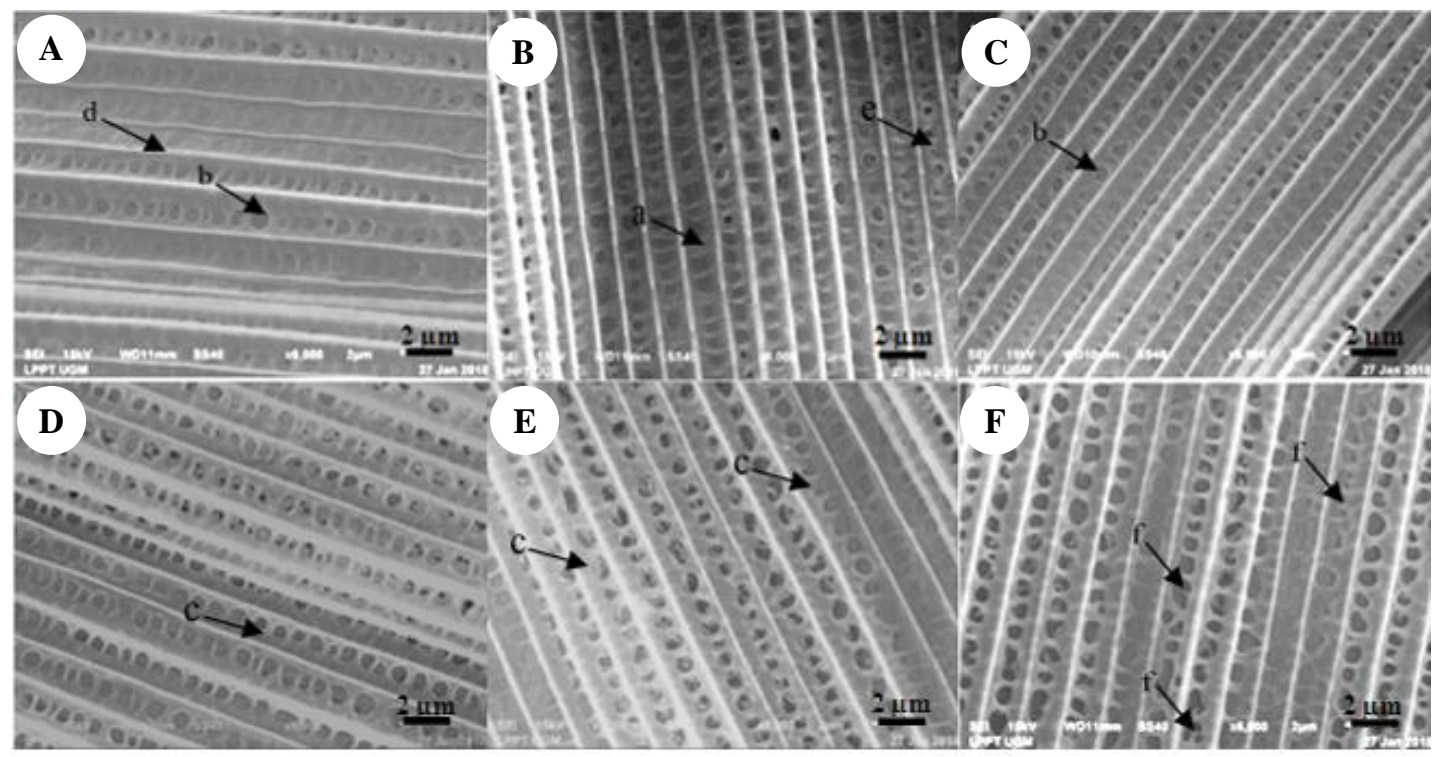

Figure 3. Ultrastructure of forewing scales of Ostrinia furnacalis from six districts of Indonesia: A. Brebes; B. Grobogan; C. Kediri; D. Tuban; E. Bantul; and F. Pekanbaru. a. crossrib (ridge lamellae); b. large window; c. microrib; d. ridge; e. small window; f. trabeculae
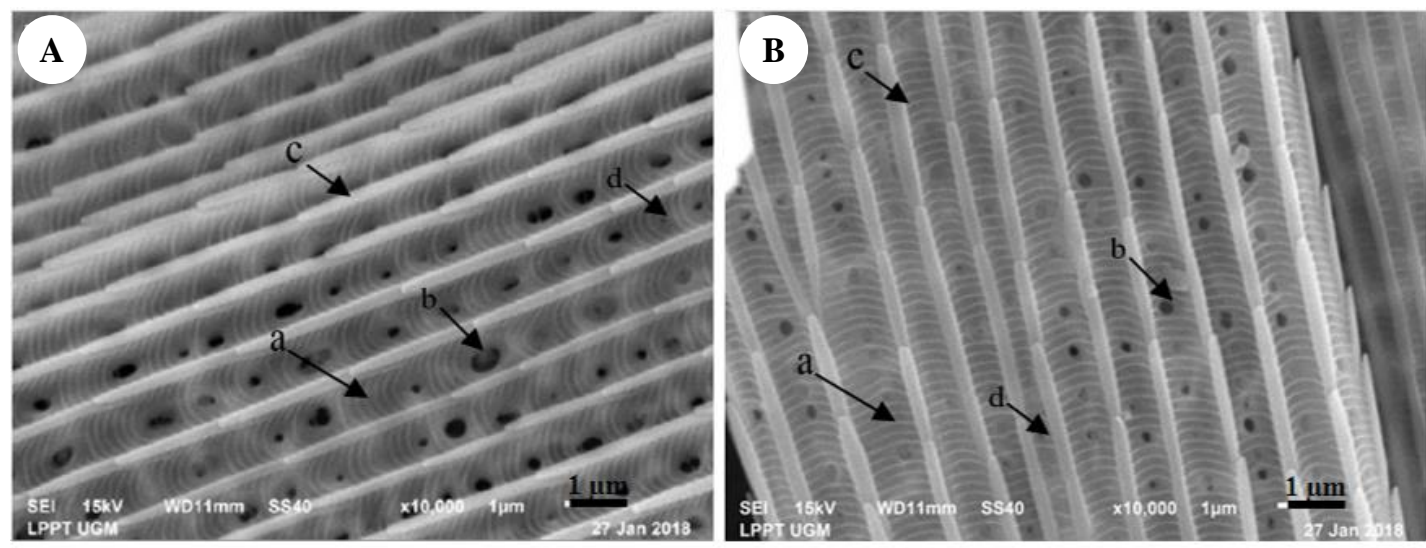

Figure 4. Comparison of ultrastructure of labial palpi scales Ostrinia furnacalis male (A) and female (B) from Grobogan District. a. crossrib (ridge lamellae); b. large window; c. ridge; d. small window

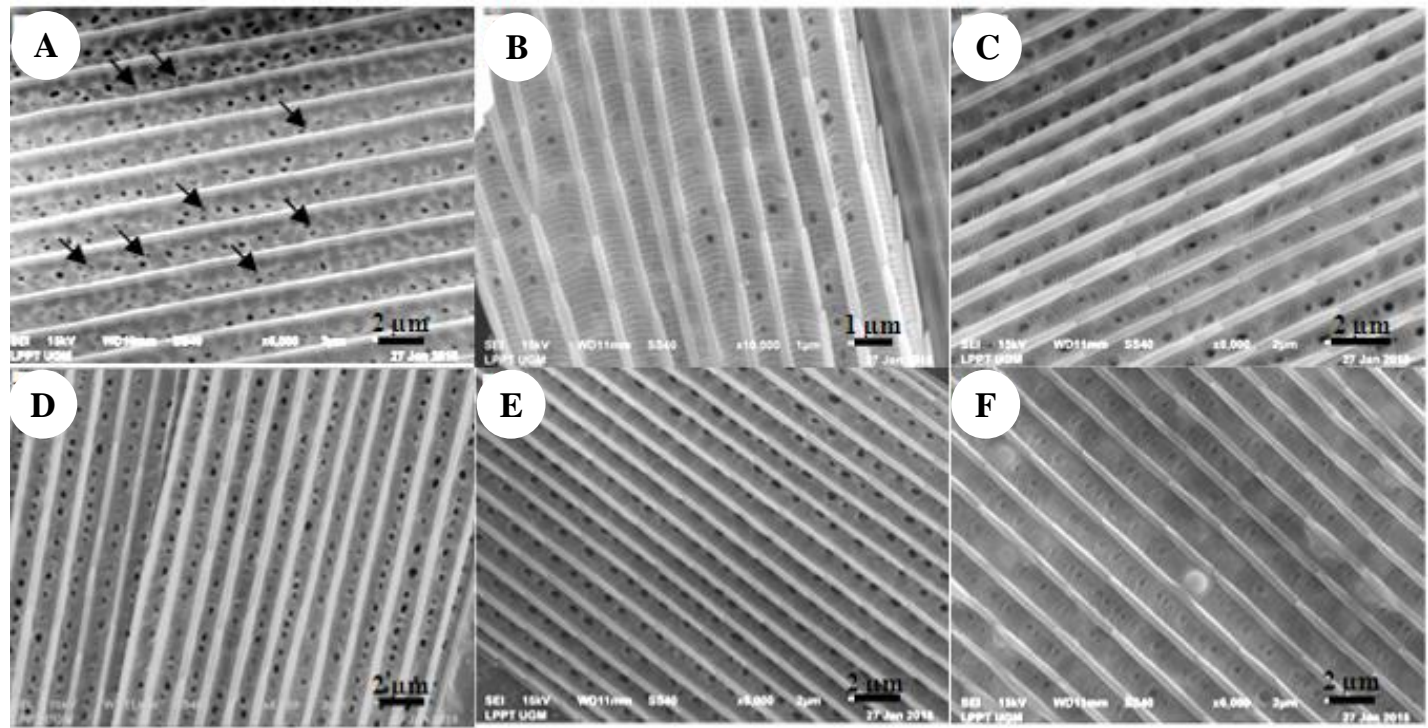

Figure 5. Ultrastructure of labial palpi scales of Ostrinia furnacalis from Districts of Brebes (A), Grobogan (B), Kediri (C), Tuban (D), Bantul (E) and Pekanbaru (F). Arrows showed irregular site of windows 


\section{Molecular analysis of partial COI gene}

All samples from Indonesia were successfully amplified and sequenced using the Lep-F/Lep-R primer as 658 bp (MK675892-MK675897). There were eight sequences of O. furnacalis based on the partial COI gene downloaded from GenBank integrated with BOLD system data, except ANICB130-06 (Table 1), and these were used for the phylogenetic analysis. All sequences from Indonesia showed highest similarity to Philippines samples (accession no. KF491966) compared to other sequences on GenBank and BOLD systems. The multiple alignment analysis showed that there was no nucleotide difference among sequences from Java, but there was a difference with sequence from Sumatra in the nucleotide position 2047
(Table 2). The base difference did not affect the amino acid in that both were equally translated into leucine. No genetic distance was observed among $O$. furnacalis sequences from Java (Brebes, Grobogan, Kediri, Tuban, and Bantul), but a distance occurred with the Sumatra (Pekanbaru) sample (Table 3). Ostrinia furnacalis from Sumatra clustered together with a bootstrap value of $>90 \%$. Sequences of $O$. furnacalis from Java and Philippines fell in the same cluster but that cluster was separated from the Australia + Asia (Pakistan, South Korea, China, and Japan) cluster in the maximum likelihood tree. However, the complete genome sequence from China was also placed in the same cluster as Indonesia and Philippines (Figure 6).

Table 1. Sequences downloaded from GenBank and BOLD systems for the phylogenetics analysis of Ostrinia furnacalis

\begin{tabular}{|c|c|c|c|c|c|}
\hline Species & $\begin{array}{c}\text { Country of } \\
\text { origin }\end{array}$ & $\begin{array}{c}\text { Accession } \\
\text { number* }\end{array}$ & Geolocation & $\begin{array}{c}\text { Collection } \\
\text { date }\end{array}$ & References \\
\hline O. furnacalis & China & AF467260 & no. information & no. information & Coates et al. (2005) \\
\hline O. furnacalis & Philippines & KF491966 & $15^{\circ} 30^{\prime} 27.0^{\prime \prime} \mathrm{N}, 120^{\circ} 46^{\prime} 08.4^{\prime \prime} \mathrm{E}$ & March 24, 1992 & Mitter (2013), ds \\
\hline O. furnacalis & Pakistan & KX862807 & $31^{\circ} 05^{\prime 20.4}{ }^{\prime \prime} \mathrm{N}, 73^{\circ} 57^{\prime} 46.8^{\prime \prime} \mathrm{E}$ & September 12, 2012 & Ashfaq et al. (2017) \\
\hline O. furnacalis & Pakistan & HQ991441 & $33^{\circ} 43^{\prime} 00.1^{\prime \prime} \mathrm{N}, 73^{\circ} 03^{\prime} 00.0^{\prime \prime} \mathrm{E}$ & June 16,2010 & Ashfaq et al. (2017) \\
\hline O. furnacalis & Japan & $\mathrm{AB} 746852$ & $37^{\circ} 24^{\prime} 00.0^{\prime \prime} \mathrm{N}, 140^{\circ} 21^{\prime} 00.0^{\prime \prime} \mathrm{E}$ & no. information & Rong et al. (2012), unpbl. \\
\hline O. furnacalis & South Korea & KC510137 & no. information & no. information & Cho et al. (2013), unpbl. \\
\hline O. furnacalis & China & JX683280 & no. information & no. information & Lassance et al. (2013) \\
\hline O. furnacalis & China & EU128666 & no. information & no. information & Yang et al. (2007), unpubl. \\
\hline O. furnacalis & Australia & ANICB130-06 & $26^{\circ} 17 ' 24.0, "$ S $146^{\circ} 03^{\prime} 36.0^{\prime \prime} \mathrm{E}$ & April 2, 2006 & Hebert et al. (2013) \\
\hline O. furnacalis & Australia & HQ952525 & $12^{\circ} 22^{\prime} 12.0, " \mathrm{~S} 131^{\circ} 03 ' 36.0^{\prime \prime} \mathrm{E}$ & May 15,1995 & Hebert et al. (2013) \\
\hline
\end{tabular}

Note: *data from GenBank except ANICB130-06 from BOLD systems; ds: direct submission; unpbl.: unpublished

Table 2. Nucleotide differences among Ostrinia furnacalis from Indonesia and other countries based on partial COI gene and the complete genome

\begin{tabular}{|c|c|c|c|c|c|c|c|c|c|c|c|c|c|c|c|c|c|}
\hline \multirow[b]{2}{*}{ Species/isolate/samples } & \multirow{2}{*}{$\begin{array}{c}\text { GenBank } \\
\text { accession } \\
\text { number }\end{array}$} & \multirow{2}{*}{$\begin{array}{l}\text { Length of } \\
\text { sequence } \\
\text { (bp) }\end{array}$} & \multirow[b]{2}{*}{$\begin{array}{c}\text { Country of } \\
\text { origin }\end{array}$} & \multicolumn{14}{|c|}{ Nucleotide difference by position (nt) } \\
\hline & & & & in & $\underset{్}{\mathscr{8}}$ & 亲 & న్ & 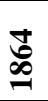 & ลู & ڤે & $\stackrel{\mathfrak{I}}{2}$ & స్తి & ষ্ণ & กิ & in & $\frac{\hat{\theta}}{\sqrt{2}}$ & $\stackrel{m}{=}$ \\
\hline O. furnacalis complete genome & AF467260 & 14.534 & China & $\mathrm{T}$ & $\mathrm{T}$ & A & $\mathrm{T}$ & $\mathrm{T}$ & $\mathrm{C}$ & $\mathrm{C}$ & $\mathrm{T}$ & $\mathrm{T}$ & $\mathrm{G}$ & A & $\mathrm{C}$ & A & $\mathrm{C}$ \\
\hline O. furnacalis Bantul-Java & MK675892* & 658 & Indonesia & . & . & . & . & . & . & . & . & . & . & . & . & . & . \\
\hline O. furnacalis Brebes-Java & MK675893* & 658 & Indonesia & . & . & . & . & . & . & . & . & . & . & . & . & . & . \\
\hline O. furnacalis Grobogan-Java & MK675894* & 658 & Indonesia & . & . & . & . & . & . & . & . & . & . & . & . & . & . \\
\hline O. furnacalis Kediri-Java & MK675895* & 658 & Indonesia & . & . & . & . & . & . & . & . & . & . & . & . & . & . \\
\hline O. furnacalis Pekanbaru-Sumatra & MK675896* & 658 & Indonesia & . & . & . & . & . & . & . & . & . & . & . & $\mathrm{T}$ & . & . \\
\hline O. furnacalis Tuban-Java & MK675897* & 658 & Indonesia & . & . & . & . & . & . & . & . & . & . & . & . & . & . \\
\hline O. furnacalis & KF491966 & 658 & Philippines & . & . & . & . & . & . & . & . & . & . & . & . & . & . \\
\hline O. furnacalis & KX862807 & 658 & Pakistan & . & . & $\mathrm{G}$ & $\mathrm{C}$ & . & $\mathrm{T}$ & . & . & $\mathrm{C}$ & . & . & . & . & . \\
\hline O. furnacalis & HQ991441 & 658 & Pakistan & . & . & G & . & . & . & . & . & $\mathrm{C}$ & . & . & . & . & . \\
\hline O. furnacalis & AB746852 & 658 & Japan & . & . & $\mathrm{G}$ & $\mathrm{C}$ & . & . & . & . & $\mathrm{C}$ & . & . & . & . & . \\
\hline O. furnacalis & KC510137 & 658 & South Korea & . & . & $\mathrm{G}$ & $\mathrm{C}$ & . & . & . & . & $\mathrm{C}$ & . & . & . & . & . \\
\hline O. furnacalis & JX683280 & 658 & China & . & . & $\mathrm{G}$ & $\mathrm{C}$ & . & . & . & . & $\mathrm{C}$ & . & . & . & . & . \\
\hline O. furnacalis & EU128666 & 658 & China & . & . & . & $\mathrm{C}$ & . & . & . & . & . & . & . & . & . & . \\
\hline O. furnacalis & ANICB130-06** & 658 & Australia & $\mathrm{C}$ & . & . & . & . & . & . & . & . & . & . & . & . & . \\
\hline O. furnacalis & HQ952525 & 658 & Australia & $\mathrm{C}$ & . & . & . & . & . & . & . & . & . & $\mathrm{T}$ & . & . & . \\
\hline
\end{tabular}


Table 3. Genetic similarity of Ostrinia furnacalis sequences from Indonesia and other countries constructed by Tamura 3 parameter

\begin{tabular}{|c|c|c|c|c|c|c|c|c|c|c|c|c|c|c|c|c|c|c|}
\hline & 1 & 2 & 3 & 4 & 5 & 6 & 7 & 8 & 9 & 10 & 11 & 12 & 13 & 14 & 15 & 16 & 17 & 18 \\
\hline 1 AF467260 compl. genome & & & & & & & & & & & & & & & & & & \\
\hline 2 AB649195 Bombyx mori & 0.120 & & & & & & & & & & & & & & & & & \\
\hline 3 EU128653 O. orientalis & 0.013 & .122 & & & & & & & & & & & & & & & & \\
\hline 4 KX050124 O. nubilalis & 0.013 & .122 & .0000 & & & & & & & & & & & & & & & \\
\hline 5 MK675896 Pekanbaru & 0.001 & .119 & .0123 & 0.0123 & & & & & & & & & & & & & & \\
\hline 6 MK675893 Brebes & 0.000 & .120 & .0139 & 0.0139 & 0.0015 & & & & & & & & & & & & & \\
\hline 7 MK675894 Grobogan & 0.000 & .120 & 0.0139 & 0.0139 & .0015 & .0000 & & & & & & & & & & & & \\
\hline 8 MK675895 Kediri & 0.000 & .120 & 0.0139 & 0.0139 & .0015 & .00000 & .0000 & & & & & & & & & & & \\
\hline 9 MK675897 Tuban & 000 & 0.120 & 0.0139 & 0.0139 & 0.0015 & .00000 & .00 & .0000 & & & & & & & & & & \\
\hline 10 MK675892 Bantul & 0.000 & 0.120 & 0.0139 & 0.0139 & 0.001 & .000 & .00 & .00 & .0000 & & & & & & & & & \\
\hline 11 KF491966 PHILIPPINES & 0.000 & 0.120 & 0.0139 & 0.0139 & .0015 & .00000 & .0000 & .0000 & .00000 & 0.0000 & & & & & & & & \\
\hline 12 KX862807 PAKISTAN & 0.006 & 0.124 & 0.0202 & 0.0202 & .0077 & .00610 & .0061 & .0061 & .00610 & 0.0061 & 0.0061 & & & & & & & \\
\hline 13 HQ991441 PAKISTAN & 0.003 & .124 & 0.0171 & 0.0171 & 0.0046 & .00310 & .0031 & .0031 & .00310 & 0.0031 & 0.0031 & 0.0031 & & & & & & \\
\hline 14 AB746852 JAPAN & 0.004 & 0.126 & 0.0186 & 0.0186 & 0.00610 & .00460 & .0046 & .0046 & .00460 & 0.0046 & 0.0046 & 0.0015 & 0.0015 & & & & & \\
\hline 15 KC510137 S. KOREA & 0.004 & .126 & 0.0186 & 0.0186 & 0.0061 & .00460 & .0046 & .0046 & .00460 & 0.0046 & 0.0046 & 0.0015 & .0015 & 0.0000 & & & & \\
\hline 16 JX683280 CHINA & 0.004 & .126 & 0.0186 & 0.0186 & 0.0061 & .00460 & .0046 & .0046 & .00460 & 0.0046 & 0.0046 & 0.0015 & .0015 & 0.0000 & 0.0000 & & & \\
\hline 17 EU128666 CHINA & 0.001 & .122 & 0.0155 & 0.0155 & 0.0031 & .00150 & .0015 & .0015 & .00150 & 0.0015 & 0.0015 & 0.0046 & .00460 & 0.0031 & 0.0031 & 0.0031 & & \\
\hline 18 HQ952525 AUS & 0.003 & .124 & 0.0170 & 0.0170 & 0.0046 & .00310 & .0031 & .0031 & .00310 & 0.0031 & 0.0031 & 0.0092 & .00610 & 0.0077 & 0.0077 & 0.0077 & 0.0046 & \\
\hline 19 ANICB130-06 AUS & 0.001 & 0.122 & 0.0155 & 0.0155 & 0.0031 & .00150 & .0015 & .0015 & .00150 & 0.0015 & 0.0015 & 0.0077 & .00460 & 0.0061 & 0.0061 & 0.0061 & 0.0031 & 0.0015 \\
\hline
\end{tabular}

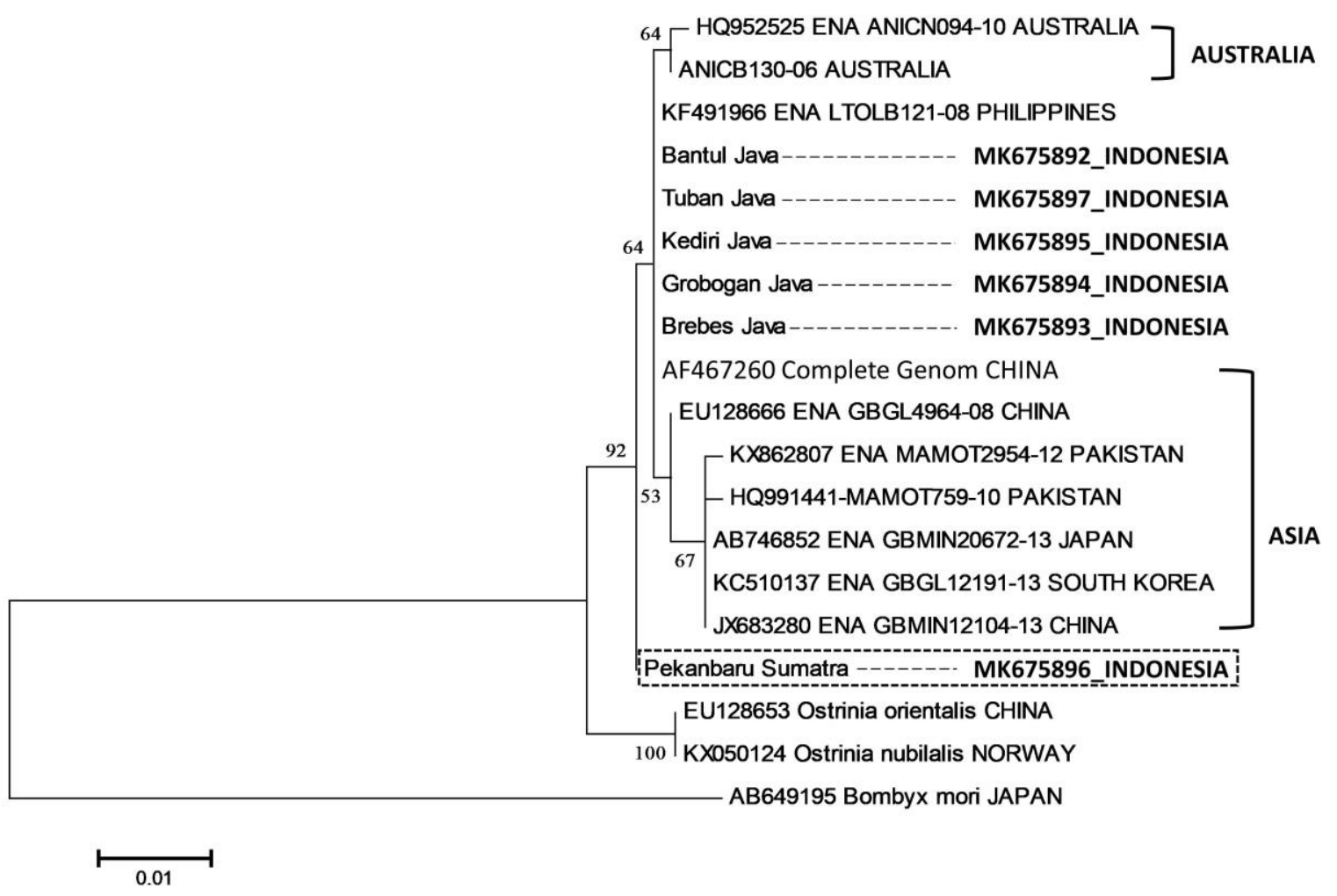

Figure 6. Maximum likelihood tree of Ostrinia furnacalis sequences from Indonesia and other countries constructed by Tamura 3 parameter (branch value was generated by 1000 bootstrap permutations)

\section{Discussion}

The characteristics of the forewing and labial palpi scales of $O$. furnacalis from Java and Sumatra islands did not show much variation. The distal dentition of the forewing scale of all samples narrowed toward the distal end similar to that of $O$. furnacalis and $O$. nubilalis as reported by Yang and Zhang (2011). The only difference in the distal dentition of the forewing scale occurred in the specimen from Sumatra (Figure 2F). This indicated that variation in the wing scales happened on wing pattern (Mutuura and Munroe 1970; Dey et al. 1998) and scale level characters (Yang and Zhang 2011; Aymone et al. 2013). Yang and Zhang (2011) considered that the ultrastructural characteristic of forewing scales was similar among $O$. furnacalis, $O$. nubilalis, and $O$. orientalis (synonymous with $O$. scapulalis according to Frolov et al. 
2007), but they were different from those of $O$. dorsivittata. The characteristics of the wing could be explored as a discriminatory character between Ostrinia species because the scales of male moths are utilized in "ultrasonic courtship" (Nakano et al. 2006; 2010; 2012), which had variations between $O$. furnacalis and $O$. nubilalis (Takanashi et al. 2010). Takanashi et al. (2010) further explained that the area of the proximal scales of the front wing and the thoracic area of the male-produced an ultrasound and exhibited different morphological characteristics specific to the species. The ultrastructure character of the labial palpi scale showed that there was no difference in the number of ridge lamellae and the size of windows between male and female $O$. furnacalis, i.e., more than two ridge lamella and mostly small in size $(0.1-0.2$ $\mu \mathrm{m})$ with some being larger $(0.3-0.4 \mu \mathrm{m})$ as shown in Figure 4. However, differences clearly occurred in the Brebes sample (Figure 5A); these findings were similar to the characters of $O$. furnacalis as described by Yang and Zhang (2011), and these characters could be used as clear indications of differences from $O$. nubilalis.

The results from the study of ultrastructure of labial palpi scales of $O$. furnacalis were consistent with the results of the molecular analysis of the COI gene (Table 2) which confirmed that all specimens were the same species. A similar finding was also reported by Kim et al. (1999) based on the target of the COII gene and the response to pheromones (Hoshizaki et al. 2008), which shows that $O$. furnacalis is different from $O$. nubilalis. All sequences of O. furnacalis based on a partial COI gene (positions of nucleotide 1480-2138) from GenBank and BOLD systems (Table 1) showed limited information compared to other mitochondrial DNA such as COII (http://ncbi.nlm.nih.gov), but it was useful and accurate enough to identify $O$. furnacalis from Indonesia. The analysis of the COI gene and characterization of the various labial palpi scales of $O$. furnacalis could be convincingly used to distinguish between the two species $O$. furnacalis and $O$. nubilalis. Comparison of $O$. furnacalis sequences from Indonesia and Philippines revealed $>99 \%$ similarity through the BLAST method (Atschul et al. 1990; Hajibabaei et al. 2006; Hebert et al. 2013; Ashfaq et al. 2017), which also confirmed that the corn borer species in Indonesia was $O$. furnacalis. This finding added accurate information regarding the identity of the corn borer species in Indonesia, which had been reported by Mutuura and Munroe (1970) and Kalshoven (1981).

The $O$. furnacalis sequences from Java and Sumatra were more identical to that from the Philippines (specimen KF491966), and had the greatest genetic distance from Asian sequences, especially with accession no. KX862807 from Pakistan. Although, the base differences of $\mathrm{T}$ and $\mathrm{C}$ on nucleotide position 2047 (Table 2) did not affect the amino acid differences, these findings indicate that were two O. furnacalis haplotypes established in Indonesia based on partial COI gene. Both of the haplotypes were haplotype 1 established in Java island and homologous with the Philippines (Table 2). Haplotype 2 was detected in Sumatra island (Pekanbaru). Haplotype 1 was also closer to specimen EU128666 from China. It indicated that lineage differences with specimen JX683280 were closer to specimen AB746852 (Table 3). These lineage differences indicated similarities with findings reported by Hoshizaki et al. (2008) in the COII gene; i.e., lineages A and B of $O$. furnacalis in Japan. The lineage A was predominant in Japan and China, whereas $O$. furnacalis from the Philippines with a unique haplotype (haplotypes 36 and 42) was lineage B. Based on these lineages, the similarities of important bio-potential properties such as resistance and reproductive ability (fitness) should be considered in the field of agriculture in Indonesia.

The phylogenetics of $O$. furnacalis from Pekanbaru (haplotype 2) was different from other regions (Figure 6). The bootstrap value in the branching of the $O$. furnacalis sequence from Pekanbaru (Sumatra) was more stable than that of the Java specimens. Branching of the Java and the Philippines (62\%) from the $O$. furnacalis sequence from Australia and Asia implied that the branching was monophyletic; it might be changed each other position in the clade (Felsenstein 1985; Wiesemüller and Rothe 2006). The COI gene characteristics analyzed in this study were known as maternal (Moore 1995; Pereira et al. 2006; Hajibabaei et al. 2006; Gullan and Cranston 2010), meaning that different lineages from ancestor mothers could cause different phylogenetics and were paraphyletic or even polyphyletic (Gullan and Cranston 2010). Those findings should be investigated in more detail by analyzing the nucleotide variation and genetic variation based on the nuclear gene to determine the relationship between these variations. The Pekanbaru District located in Riau Province, in the middle of Sumatra Island, is known to have small agricultural corn areas (approximately 1,600 ha) (BPS 2018). The Pekanbaru area was extensively peatland areas with typical peatland vegetation, which was different from those in Java Island. This may potentially provide different alternative hosts to $O$. furnacalis. The alternative hosts of $O$. furnacalis are known to be several plants from the families Poaceae, Zingiberaceae, Polygonaceae, Asteraceae (Ishikawa et al. 1999), Malvaceae, and Solanaceae (https://www.plantwise.org). According to Frolov et al. (2007), host differences affect mating success and is implicated in their heritability. However, Shashank et al. (2014) found that it could be a cryptic phenomenon. A study of alternative hosts of $O$. furnacalis in the peatland area and in Java, a central area of maize production in Indonesia, may become an essential component in understanding the genetic differences among the population of $O$. furnacalis.

To conclude, the ultrastructural characteristics of the labial palpi scales provide important information regarding the "ridge lamellae" and "windows" characteristics for the identification of $O$. furnacalis in Indonesia. These characters were strongly supported by the analysis of the COI gene with a target nucleotide position of 1480-2138, which showed high similarity between $O$. furnacalis from Indonesia and $O$. furnacalis from the Philippines. There were two $O$. furnacalis haplotypes present in Indonesia, haplotype 1 from Java and haplotype 2 from Sumatra; $O$. furnacalis from Java has a closer relationship with $O$. furnacalis from the Philippines than with that of Sumatra. 


\section{ACKNOWLEDGEMENTS}

We thank Dr. Susi Melina and Sukirno, Ph.D. for their constructed suggestions to this manuscript. We also thank Publishers and Publications Board of Universitas Gadjah Mada, Yogyakarta, Indonesia for the funding of proofreading this manuscript. This research was supported by Ministry of Finance, Republic of Indonesia through Indonesia Endowment Fund for Education (LPDP) no. contract: PRJ-1485/LPDP.3/2017.

\section{REFERENCES}

Altschul SF, Gish W, Miller W, Myers EW, Lipman DJ. 1990. Basic local alignment search tool. J Mol Biol 215: 403-410. DOI: 10.1016/S0022-2836(05)80360-2

Ashfaq M, Akhtar S, Rafi MA, Mansoor S, Hebert PDN. 2017. Mapping global biodiversity connections with DNA barcodes: Lepidoptera of Pakistan. PLoS ONE 12. e0174749. DOI: 10.1371/journal.pone.0174749.

Aymone ACB, Valente VLS, De Araujo AM. 2013. Ultrastructure and morphogenesis of the wing scales in Heliconius eratophyllis (Lepidoptera: Nymphalidae): what silvery/brownish surface can tell us about the development of color patterning? Arthropod Struct Dev 42: 349-359. DOI: 10.1016/j.asd.2013.06.001.

BPS [Badan Pusat Statistik, Berau Statistics Center of Indonesia]. 2018 Statistical Yearbook of Indonesia 2018. Sub-directorate of Statistical Compilation and Publication. Badan Pusat Statistik-Statistics Indonesia. BPS-Statistics Indonesia, Jakarta. [Indonesian].

Brindle TA, Dicke FF. 1963. Significant developments in European corn borer research. Ann Rev Entomol 8: 155-176. DOI 10.1146/annurev.en.08.010163.001103

Coates BS, Sumerford DV, Hellmich RL, Lewis LC. 2005. Partial mitochondrial genome sequence of Ostrinia nubilalis and Ostrinia furnacalis. Int J Biol Sci 1: 13-18. DOI: 10.7150/ijbs.1.13

Dey S, Hooroo RNK, Bhattacharjee CR. 1998. Electron microscopy and spectroscopical studies on the coloured patches on the wing of a butterfly, Graphium sarpedon (Lepidoptera: Papilionidae) with reference to their photobiological and electrical properties. Pigment Cell Res 11: 1-11. DOI: 10.1111/j.1600-0749.1998.tb00704.x

Downey JC, Allyn AC. 1975. Wing-scale morphology and nomenclature. Bul Allyn Museum 31: 1-32.

Felsenstein J. 1985. Confidence limits on phylogenies: an approach using the bootstrap. Evolution 39: 783-791. DOI: 10.1111/j.15585646.1985.tb00420.x

Frolov AN, Bourguet D, Ponsard S (2007) Reconsidering the taxonomy of several Ostrinia species in the light of reproductive isolation: a tale for Ernst Mayr. Biol J Linn Soc 91: 49-72. DOI: 10.1111/j.10958312.2007.00779.x

Ghosh S, Mishra M. 2018. Fine nanostructural variation in the wing pattern of a moth Chiasmia eleonora Cramer (1780). J Biosci 43 (4) 673-684. DOI: 10.1007/s12038-018-9793-y.

Gullan PJ, Cranston PS. 2010. The Insects: an Outline of Entomology. Wiley-Blackwell, United Kingdom.

Hajibabaei M, Janzen DH, Burns JM, Hallwachs W, Hebert PDN. 2006 DNA barcodes distinguish species of tropical Lepidoptera. Proc Nat Acad Sci USA 103: 968-971. DOI: 10.1073/pnas.0510466103

Hall TA. 1999. BioEdit: A User-Friendly Biological Sequence Alignment Editor and Analysis Program for Windows 95/98/NT. Nuc Acids Symp Ser 41: 95-98. DOI: 10.1021/bk-1999-0734.ch008

Hebert PDN, Penton EH, Burns JM, Janzen DH, Hallwachs W. 2004. Ten species in one: DNA barcoding reveals cryptic species in the neotropical skipper butterfly Astraptes fulgerator. Proc Nat Acad Sci USA 101: 14812-14817. DOI: 10.1073/pnas.0406166101

Hebert PDN, DeWaard JR, Zakharov EV, Prosser SW, Sones JE, McKeown JA, Mantle B, Salle JL. 2013. A DNA 'Barcode Blitz' rapid digitation and sequencing of a natural history collection. PLoS ONE 8: e68535. DOI: 10.1371/journal.pone.0068535

Hoshizaki S, Washimori R, Kubota S, Ohno S, Huang Y, Tatsuki S, Ishikawa Y. 2008. Two mitochondrial lineage occur in the Asian corn borer. Ostrinia furnacalis (Lepidoptera: Crambidae), in Japan. Bull Entomol Res 98: 519-526. DOI: 10.1017/S0007485308005841

Ishikawa Y, Takanashi T, Kim C, Hoshizaki S, Tatsuki S, Huang YP. 1999. Ostrinia spp. in Japan: their host plants and sex pheromones. Entomol Exp Appl 91: 237-244. DOI: 10.1007/978-94-017-18905_30

Kalshoven LGE. 1981. The pests of crops in Indonesia. IchtiarBaru-Van Hoeve, Jakarta.

Kim CG, Hoshizaki S, Huang YP, Tatsuki S, Ishikawa Y. 1999. Usefulness of mitochondrial COII gene sequences in examining phylogenetic relationships in the Asian corn borer, Ostrinia furnacalis, and allied species (Lepidoptera: Pyralidae). Appl Entomol Zool 34: 405-412. DOI: 10.1303/aez.34.405

Lassance JM, Lienard MA, Antony B, Qian S, Fujii T, Tabata J, Ishikawa Y, Löfstedt C. 2013. Functional consequences of sequence variation in the pheromone biosynthetic gene pgFAR for Ostrinia moths. Proc Nat Acad Sci USA 110: 3967-3972. DOI: 10.1073/pnas.1208706110

Li J, Coates BS, Kim KS, Bourguet D, Ponsard S, He K, Wang Z. 2014. The Genetic structure of Asian corn borer, Ostrinia furnacalis, populations in China: haplotype variance in Northern populations and potential impact on management of resistance to transgenic maize. J Hered 105: 642-655. DOI: 10.5061/dryad.8p8tg

Moore WS. 1995. Inferring phylogenies from mtDNA variation: mitochondrial-gene trees versus nuclear-gene trees. Evolution 49: 718-726. DOI: $10.2307 / 2410325$

Mutuura A, Munroe E (1970) Taxonomy and distribution of the European corn borer and allied species (genus Ostrinia). Memoirs Entomol Soc Can 71: 1-112. DOI: 10.4039/entm10271fv

Nakano R, Ishikawa Y, Tatsuki S, Surlykke A, Skals N, Takanashi T. 2006. Ultrasonic courtship song in the Asian corn borer moth, Ostrinia furnacalis. Naturwissenschaften 93: 292-296. DOI: 10.1007/s00114-006-0100-7.

Nakano R, Takanashi T, Skals N, Surlykke A, Ishikawa Y. 2010. Ultrasonic courtship songs of male Asian corn borer moths assist copulation attempts by making the females motionless. Physiol Entomol 35: 76-81. DOI: 10.1111/j.1365-3032.2009.00712.x.

Nakano R, Ihara R, Mishiro K, Toyama M. 2012. Male courtship ultrasound produced by mesothoracic tymbal organs in the yellow peach moth Conogethes punctiferalis (Lepidoptera: Crambidae). Appl Entomol Zool 47: 129-135. DOI: 10.1007/s13355-012-0099-5.

Pereira F, Carneiro J, Amorim A. 2006. Identification of species with DNA-based technology: current progress and challenges. Rec Patents DNA Gen Seq 2: 187-200. DOI: 10.2174/187221508786241738.

Rahayu T, Trisyono YA, Witjaksono. 2018. Fitness of Asian corn borer, Ostrinia furnacalis (Lepidoptera: Crambidae) reared in and artificial diet. J Asia-Pac Entomol 21: 823-828. DOI: 10.1016/j.aspen.2018.06.003.

Shashank PR, Chakravarthy AK, Raju BR, Bhanu KRM. 2014. DNA barcoding reveals the occurrence of cryptic species in host-associated population of Conogethes punctiferalis (Lepidoptera: Crambidae). Appl Entomol Zool 49: 283-295. DOI: 10.1007/s13355-014-0248-0

Siddique RH, Vignolini S, Bartels S, Wacker I, Hölscher H. 2016. Colour formation on the wings of the butterfly Hypolimnas salmacis by scale stacking. Sci Rep 6: 36204. DOI: 10.1038/srep36204.

Sihvonen P, Mutanen M, Kaila L, Brehm G, Hausmann A, Staude HS. 2011. Comprehensive molecular sampling yields a robust phylogeny for geometrid moths (Lepidoptera: Geometridae). PLoS ONE 6(6): e20356. DOI: 10.1371/journal.pone.0020356

Sutrisno H. 2015. Phylogenetic relationships within Arctornis (Lepidoptera: Erebidae) based on COI gene sequences. Hayati J Biosci 22: 6-11. DOI: 10.4308/hjb.22.1.6

Takanashi T, Nakano R, Surlykke A, Tatsuta H, Tabata J, Ishikawa Y, Skals N. 2010. Variation in courtship ultrasounds of three Ostrinia moths with different sex pheromones. PLoS ONE 5: e13144. DOI: 10.1371/journal.pone.0013144

Tamura K, Stecher G, Peterson D, Filipski A, Kumar S. 2013. MEGA6: Molecular Evolutionary Genetics Analysis version 6.0. Mol Biol Evol 30: 2725-2729. DOI: 10.1093/molbev/mst197

Thompson JD, Higgins DG, Gibson TJ. 1994. CLUSTAL W: improving the sensitivity of progressive multiple sequence alignment through sequence weighting, positions-specific gap penalties and weight matrix choice. Nucleic Acids Res 22: 4673-4680. DOI: 10.1093/nar/22.22.4673

Wang Y, Kim KS, Guo W, Li Q, Zhang Y, Wang Z, Coates BS. 2017. Introgression between divergent corn borer species in a region of 
sympatry: implications on the evolution and adaptation of pest arthropods. Mol Ecol 26: 6892-6907. DOI: 10.1111/mec.14387.

Wiesemüller B, Rothe H. 2006. Interpretation of bootstrap values in phylogenetic analysis. Anthrop Anz 64: 161-165.

Yang Z, Zhang Y. 2011. Comparison of ultrastructure among sibling species of Ostrinia (Lepidoptera: Crambidae) from China. Can Entomol 143: 126-135. DOI: 10.4039/n10-049.
Zhang DX, Hewitt GM. 1997. Insect mitochondrial control region: a review of its structure, evolution and usefulness in evolutionary studies. Biochem Syst Ecol 25: 99-120. DOI: 10.1016/S03051978(96)00042-7. 